\title{
Moderating Effect of External Operating Environment on the Relationship Between Corporate Strategies and Performance of Manufacturing Firms in Nairobi City County, Kenya
}

\author{
Alexander Irungu Wanjiru* \\ School of Business, Kenyatta University, Nairobi, Kenya, P.O Box 8903-00100, Nairobi, Kenya \\ Stephen Makau Muathe \\ School of Business, Kenyatta University, Nairobi, Kenya, P.O. Box 43844 00100, Nairobi, Kenya \\ Jane W.Kinyua-Njuguna \\ School of Business, Kenyatta University, Nairobi, Kenya, P.O. Box 43844 00100, Nairobi, Kenya
}

\begin{abstract}
Theoretical propositions in strategic management show that the external operating environment of a firm influences the relationship between other organizational factors and performance. However, most of the arguments have been directed at firms that exist in the context of developed economies, with little attention to firms in developing economies such as the ones in Africa. This paper examines the moderating effect of external operating environment on the relationship between corporate strategies and performance of manufacturing firms in Nairobi City County, Kenya; which is a developing economy within Sub-Saharan Africa. The authors adopted indicators of competitive position, consumer behaviour and credit accessibility to measure external operating environment.Multistage probability sampling technique was used to select study sample out of a target population of 373 firms located in Nairobi City County where $80 \%$ of the country's manufacturing firms are situated. The study collected primary data using a semi-structured questionnaire from 148 firms. The data was analysed using descriptive and inferential statistics for quantitative data and content analysis to analyze qualitative data. The study findings indicate that external operating environment has a moderating effect on the relationship between corporate strategies and firm performance. Based on this, the study recommends development of policies and legislative framework to regulate manufacturing sector's competition practices, review of fiscal and monetary policies, and customer awareness programs to address consumer perceptions and attitude towards firms' products.

Keywords: Market development, Product development, Diversification, External operating environment, Firm performance
\end{abstract}

DOI: $10.7176 / \mathrm{EJBM} / 11-14-05$

Publication date:May $31^{\text {st }} 2019$

\subsection{INTRODUCTION}

Firms operate within external environment that constitutes varied factors which determine performance. The concept of firm performance has been addressed in most strategic management studies as outcome of three factors, which are firm strategy (Mazdeh, Moradi \& Mazdeh, 2011); competitive advantage (Hosseini \& Sheikh, 2012); and business environment (Tan \& Liu, 2014). According to Neneh and Vanzyl (2014) firm external operating environment include forces some of which the firm management cannot control thus bringing forth threats and opportunities in equal measures to the firm. The external operating factors affect firm strategic options. Some of the external factors include; competitive position, consumer behaviour, market changes and credit availability (Kim \& Lim, 1988; Powell, 1996; Spanos, Zaralis \& Lioukas, 2004; Pearce \& Robinson, 2013).Therefore, firm strategies should be adequate to fit into the external operating environment so as to efficiently enhance performance of manufacturing firms in the developing economies (Eljelly, 2004; Padachi, 2006). However, according to Filbeck and Krueger (2005); Raheman and Nasr (2007) existing external operating environment in developing countries may be restrictive towards firm performance.

Hosseini and Sheikhi (2012) also concluded that the external environment influence firm performance. This argument is supported by empirical findings of Jong, Phan and Van Ees (2011) which identified external operating environment as a determinant of firm performance. Grant and Perren (2002) opined that firms operate in an external context comprising of dimensions that affect how the firms develop their competencies, and as Njuguna, Munyoki and Kibera (2014) found out, organizational performance is influenced by external environment. Hawawini, Subramanian and Verdin (2003); Konar and Cohen (2001) opined that firm external environment determines the level of competitiveness of different firms within an industry, and thus a specific environmental factor may confer a comparative advantage on a firm against competitors. Consistent with these views, Kenya Association of Manufacturers (KAM) report (2016) indicated that competition, consumer (customer) preferences and credit unavailability are some of the challenges facing the manufacturing firms in Kenya. Foss and Knudsen 
(2003) contend that firm performance is attributed to the impact of its external operating environment.

In order to sustain survival, organizations compete for resources, market dominance, acquisition and control of customers which are components of external operating environment (DiMaggio \& Powell, 1983; Scott, 1995). This is consistent with Porter's (2008) views that the organization's threats and opportunities originate from the external operating environment. Based on theoretical propositions, it can be concluded that superior firm performance results from adequate management of external environmental factors and employing appropriate corporate strategies.

\subsection{LITERATURE REVIEW}

In this study, two theories were adopted to describe the role of external operating environment on firm performance; these were Institutional theory and Resource Dependency theory. Several authors advance varied propositions of firm external operating environment based on the theory adopted. The institutional theory postulates that institutional pressures lead organizations to adopt structures, strategies, and processes in order to reduce environmental uncertainty (Scott, 1995). This theory posits that organizational adaptation is important because a mismatch between organizational strategies and the operating environment can lead to misfit between organizational goals and the market expectation (Greenwood, Oliver, Suddaby \& Sahlin 2008)

The Resource Dependency theory states that the firm's key determinant of performance will be contingent on its resources and the external environment (Hillman, Cannella \& Paetzold, 2000). The theory mainly focuses on the dependency of the firm on the environment for critical resources that lead to successful performance (Chin, Widing \& Paladino, 2004).The theory postulates that superior organizational performance may result from managing uncertainty and choosing the appropriate strategies to proactively influence and control the external operating environment to the advantage of the organization (Davis \&Cobb, 2010).

Empirical studies have been conducted to examine the effect of external operating environment. Hidayat, Sabarudin and Mu'alim (2015) found out that external operating environment affected the relationship between corporate strategies and performance of manufacturing firms in Indonesia. Henk, Niels, Ernst, Marten and Antonio (2012) concluded that firms without strong adaptation towards institutional fit in their operating environment decrease their performanceacross different industries in Netherlands. Hsiang, Hsien and Dja-Shin (2012) found out that operating environment had significant impact on relationship between corporate strategies and performance among Taiwan manufacturing firms. Adeoye and Elegunde (2012) concluded that external environment affected performance of food and beverage manufacturing firms in Nigeria.

\subsection{CONCEPTUAL FRAMEWORK FOR THE STUDY}

The conceptual framework for measuring the effect of external operating environment on relationship between corporate strategies and firm performance is developed from the study theoretical and empirical literature reviews. The study conceptualizes that corporate strategies' effect on firm performance is moderated by external operating environment. The variable of external operating environment is indicated by competitive position, consumer behaviour and credit accessibility. 


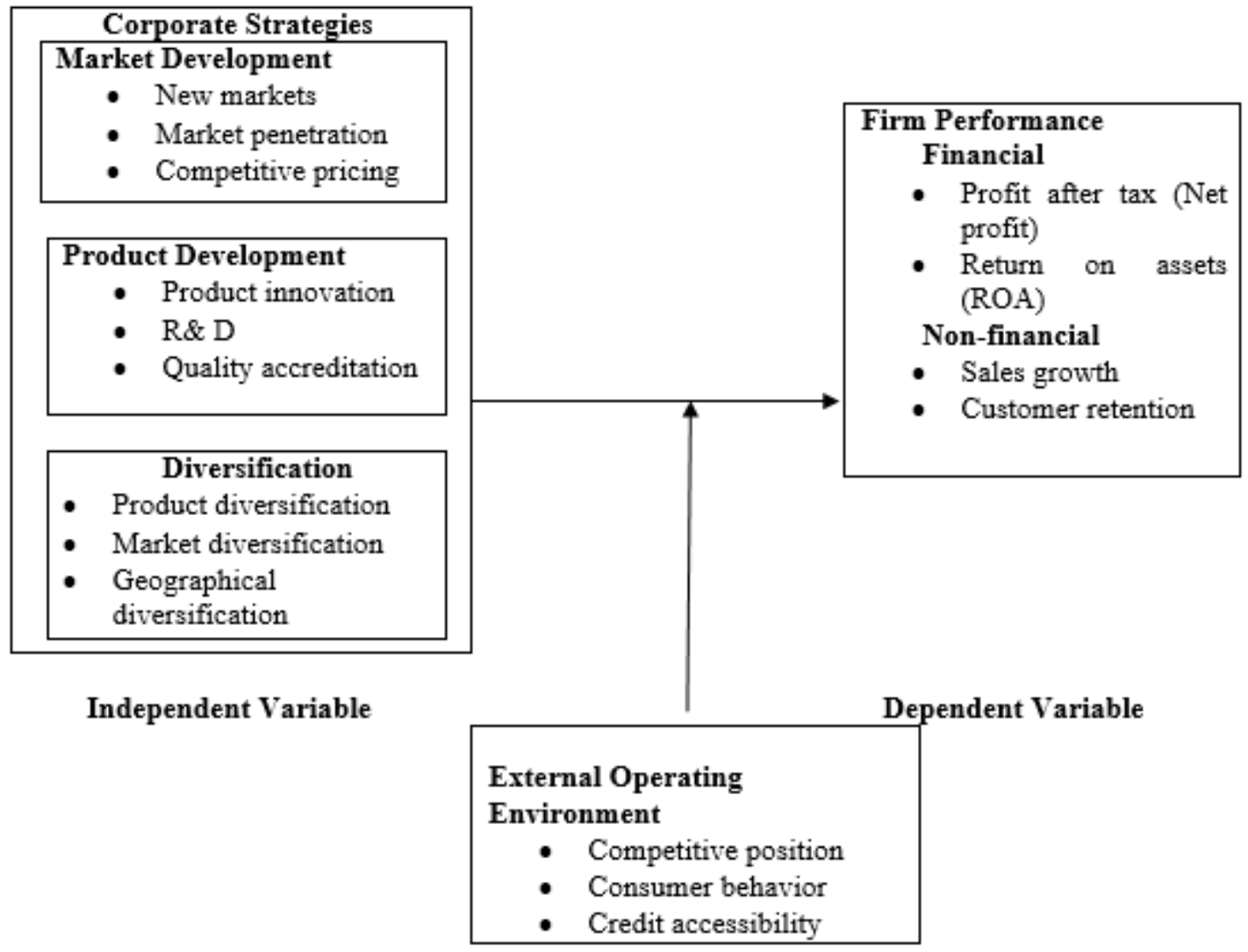

\section{Moderating Variable}

Figure 1: Conceptual Framework

Source: Literature Review (2017)

Based on figure 1 the following hypothesis was developed:

$\mathrm{H}_{01}$ : External operating environment has no significant moderating effect on the relationship between corporate strategies and performance of manufacturing firms in Nairobi City County, Kenya.

\subsection{METHODOLOGY}

The study adopted both descriptive and explanatory survey design as recommended by Sekaran and Bougie (2009). The descriptive and explanatory survey designs enable studies to test hypotheses quantitatively (Njuguna, Munywoki \& Kibera, 2014). Additionally, the use of more than one research design was meant to triangulate research findings raising validity of the results as recommended by Saunders, Lewis and Thornhill (2009).The descriptive design helped the researcher to capture the characteristics of the population and study variables in their natural situation (Cooper \& Schindler, 2003; Burns \& Grove, 2007). Explanatory design was used to explain relationships between variables (Kothari, 2004).According to Mugenda and Mugenda (2003) explanatory study is conducted in order to test hypothesis on why certain situation is occurring. This design helped the researcher to test study hypotheses. Zikmund (2003) explained that survey approach in research provides quick and accurate method of accessing study data, helping the researcher to establish whether there is significant relationship between variables within target population at specific point in time.

The study targeted 373 manufacturing firms based in Nairobi City County, Kenya categorised as large by the Kenya Association of Manufacturers. Out of the target population, a sample size of 189 firms was obtained through multi-stage sampling method as recommended by Shapiro, Carlson, Astin, and Freedman (2006). The steps of determining sample size was proportionate stratified sampling defined by sub- sector, which are categorized by what they produce (KAM, 2016). A sample size of 189 firms was used in the current study which was arrived at using the formula suggested by Fisher, Laing and Stoeckel (1985) as follows:

$$
\begin{aligned}
& \mathrm{n}=\frac{\mathrm{Z}^{2} \alpha / 2 \mathrm{pq}}{\mathrm{d} 2} \mathrm{n}=(1.96) 2(0.50) \frac{(0.50)}{(0.05) 2}=\mathbf{3 8 4} \\
& \mathrm{n}_{\mathrm{f}}=\frac{\mathrm{N}}{1+\mathrm{n} / \mathrm{N}} \mathrm{n}_{\mathrm{f}}=
\end{aligned}
$$


Where:

$\mathrm{n}_{\mathrm{f}}=$ is the desired sample size (when the population is less than 10,000).

$\mathrm{N}=$ the Population (in this case 373 firms).

$\mathrm{n}=$ the desired sample size (if the target population is greater than 10,000)

$\mathrm{z}=$ the degree of confidence (in this case $95 \%$ confidence interval, $\alpha=1.96$ )

$\mathrm{p}=$ the proportion in the target population estimated to have characteristics being measured. 50\% chosen as recommended by Fisher et al., (1985)

$\mathrm{d}=$ the level of statistical significance (set at $5 \%$ ).

Finally, a simple random sampling was conducted to select specific firms to participate in the study with chief executive officers/managing directors and directors as the units of observation. Foya, Kilika and Muathe (2015) used the multistage sampling method in their study. One hundred and forty eight questionnaires were received back which translated to a response rate of $78.30 \%$. Data were analyzed using descriptive statistics, simple and step-wise regression analysis.

In testing for moderation,Whisman and MacClelland (2005) explained that the test involves determining the statistical significance of coefficient for the interaction term. Therefore, in order to test the moderating effect of external operating on the relationship between corporate strategies and firm performance, models 1.1 as base model, 1.2 and 1.3 were estimated as follows;

$\mathrm{Y}=\beta_{0}+\beta_{1} \mathrm{X}_{1}+\mathrm{X}_{2}+\mathrm{X}_{3}+\varepsilon$

$\mathrm{Y}=\beta_{0}+\beta_{4} \mathrm{CS}+\beta_{5} \mathrm{EOE}+\varepsilon$

Where;

$\mathrm{Y}=$ Firm performance

$\beta_{0}=$ Constant (intercept)

$\beta_{4}$ and $\beta_{5}=$ Beta coefficients

$\mathrm{CS}=$ Composite index for market development, product development and diversification

$\mathrm{EOE}=$ External operating environment

$\varepsilon=$ Error term

Finally, model 1.3 was used to provide the direction and effect of the external operating environment on corporate strategies and the total effect of the moderator on form performance by showing the interaction between operating environment and corporate strategies. The model was as follows;

$\mathrm{Y}=\beta_{0}+\beta_{4} \mathrm{CS}+\beta_{6} \mathrm{CS} * \mathrm{EOE}+\varepsilon$.

Where;

$\mathrm{Y}=$ Firm performance

$\beta_{0}=$ Constant

$\beta_{4}$ and $\beta_{6}=$ Beta coefficients

$\mathrm{CS}=$ Composite index for market development, product development and diversification

$\mathrm{CS} * \mathrm{EOE}=$ Corporate strategies $\mathrm{x}$ External operating environment

$\varepsilon=$ Error term

The decision-making criteria for moderation are summarized in Table 1.

Table 1: Moderation Decision Making Criteria

\begin{tabular}{|l|l|l|l|}
\hline Model 1.2 & Model 1.3 & Total effect & Conclusion \\
\hline $\begin{array}{l}\mathrm{B}_{4} \text { is not significant } \\
(\mathrm{p}>0.05)\end{array}$ & - & - & No moderation \\
\hline $\begin{array}{l}\mathrm{B}_{4} \text { is significant } \\
(\mathrm{p}<0.05)\end{array}$ & $\begin{array}{l}\mathrm{B}_{6} \text { is not significant } \\
(\mathrm{p}>0.05)\end{array}$ & - & $\begin{array}{l}\text { Moderating variable } \\
\text { is an explanatory variable }\end{array}$ \\
\hline $\begin{array}{l}\mathrm{B}_{4} \text { is significant } \\
(\mathrm{p}<0.05)\end{array}$ & $\begin{array}{l}\mathrm{B}_{6} \text { is significant } \\
(\mathrm{p}<0.05)\end{array}$ & $\beta_{3}$ & $\begin{array}{l}\text { Moderating variable } \\
\text { has a moderating effect }\end{array}$ \\
\hline
\end{tabular}

Source: Whisman and MacClelland (2005)

\subsection{RESULTS AND DISCUSSION}

The study targeted 189 large manufacturing firms whereby the unit of observation was CEO / managing director or director of the companies. Out of the 189 issued questionnaires, 41 were not responded to, while148 were properly filled and returned thus translating to a response rate of $78.30 \%$. According to Mugenda and Mugenda (2003) a response rate of $50 \%$ and above is satisfactory hence this response rate was satisfactory.

\subsection{Validity and Reliability}

The validity and reliability of the study measurements were assessed before survey data was analysed. The instrument was subjected to a panel of experts to determine the content validity. Confirmatory factor analysis (CFA) was used to investigate construct validity of the instrument as recommended by Patton (2002).According to Rahim and Magner (2005)an instrument is said to fulfil construct validity when Eigen values are greater than 
1.0 and loadings greater than 0.4 . Therefore, the research instrument had adequate construct validity since all the items had Eigen values greater than 1.0 and loadings greater than 0.4 .

A pilot study using 20 respondents who were part of the study population was done to test for reliability of research instrument. The findings are shown in Table 2.

Table 2: Summary of the Reliability Tests

\begin{tabular}{lcll}
\hline Variable & Cronbach's Alpha & N of Items & Remarks \\
\hline Market development strategy & .895 & 11 & Reliable \\
Product development strategy & .868 & 09 & Reliable \\
Diversification strategy & .839 & 10 & Reliable \\
External operating Environment & .931 & 22 & Reliable \\
Competitive advantage & .847 & 27 & Reliable \\
Overall & $\mathbf{. 8 7 6}$ & $\mathbf{7 9}$ & Reliable \\
\hline
\end{tabular}

Source: Pilot Study (2018).

From the findings presented in Table 2, the Cronbach's Alpha for all the variables were found to be above 0.7 threshhold, as recommended by Sekaran and Bougie (2009). The alpha coefficients of each evaluated variable was above 0.8 which was very close to 1 implying that the level of reliability was very good as recommended by Hair,Money,Samouel and Page (2007).

\subsection{Descriptive Statistics}

The study investigated three components of the moderating variable namely competitive position, credit accessibility and consumer behaviour. The study findings are shown in Tables 3, 4 and 5 .

\subsubsection{Competitive position}

The respondents were asked to rate firm competitive position as a component of external operating environment on a Likert type scale of 1-5, where strongly agree $=5$, Agree $=4$, Disagree $=3$, strongly disagree $=2$ and Not at all $=1$. The findings are shown in Table 3 .

\section{Table 3: Descriptive Statistics of Competitive Position}

\begin{tabular}{|l|c|c|}
\hline Statement & Mean & $\begin{array}{l}\text { Std. } \\
\text { Deviation }\end{array}$ \\
\hline Firm competitive position is restricted by industry competition & 4.13 & 0.890 \\
\hline Firm competitive position is restricted by lack of industry infrastructure & 3.77 & 0.984 \\
\hline Firm competitive position is threatened by new industry entrants & 3.86 & 1.190 \\
\hline Firm competitive position is negatively affected by industry entry barriers & 3.84 & 1.123 \\
\hline Firm competitive position is threatened by substitute products & 3.80 & 1.060 \\
\hline $\begin{array}{l}\text { Firm competitive position is restricted by lack of related and supporting } \\
\text { internationally competitive industries }\end{array}$ & 3.78 & 1.072 \\
\hline $\begin{array}{l}\text { Firm competitive position is restricted by lack of government's supportive } \\
\text { business environment }\end{array}$ & 3.57 & 1.017 \\
\hline $\begin{array}{l}\text { Firm competitive position is negatively affected by bargaining power of } \\
\text { customers }\end{array}$ & 3.64 & 1.155 \\
\hline Average & $\mathbf{3 . 8 0}$ & $\mathbf{1 . 0 6}$ \\
\hline
\end{tabular}

Source: Survey data (2018)

The findings in Table 3 indicate that the manufacturing firms' competitive position is mainly restricted by industry competition, threatened by new industry entrants and negatively affected by industry entry barriers. Despite the effects of other factors restricting the firm competitive position, lack of government's supportive business environment, bargaining power of customers, and lack of industry supporting infrastructure least affect the firm competitive position. The aggregate mean score round off to a score of 4 on the five point Likert type scale implying that the respondents agreed that the firm's external operating environment (competitive position) affect relationship between corporate strategies and performance. The findings agreed with Hidayat, Sabarudin and Mu'alim (2015) study, which established that external environment, affected corporate strategies and performance of manufacturing industries in Indonesia.

\subsubsection{Credit Accessibility}

The respondents were asked to rate firm credit accessibility as a component of external operating environment on a Likert type scale of $1-5$, where strongly agree $=5$, Agree $=4$, Disagree $=3$, strongly disagree $=2$ and Not at all $=1$. The findings are shown in Table 4. 
Table 4: Descriptive Statistics of Credit Accessibility

\begin{tabular}{|l|l|l|}
\hline Statement & Mean & $\begin{array}{l}\text { Std. } \\
\text { Deviation }\end{array}$ \\
\hline Firm credit accessibility is restricted by government taxation regimes & 3.52 & 1.22 \\
\hline Firm credit accessibility is negatively affected by government fiscal policy credit & 3.46 & 1.214 \\
\hline $\begin{array}{l}\text { Government regulation of loan interest rates negatively affect firm's credi } \\
\text { accessibility }\end{array}$ & 3.29 & 1.132 \\
\hline $\begin{array}{l}\text { Unstable inflation and currency exchange rates negatively affect firm's credit } \\
\text { accessibility }\end{array}$ & 3.41 & 1.106 \\
\hline Firm's financial performance influences credit accessibility & 3.31 & 1.217 \\
\hline Firm credit accessibility is negatively affected by government domestic borrowing & 3.49 & 1.128 \\
\hline Firm performance is negatively affected by lack of global credit accessibility & 4.27 & 0.83 \\
\hline Average & $\mathbf{3 . 5 4}$ & $\mathbf{1 . 1 2}$ \\
\hline
\end{tabular}

Source: Survey data (2018)

The findings in Table 4 indicate that lack of global credit accessibility, government taxation regime; government domestic borrowing and fiscal policy are the main factors that negatively determine credit accessibility of the manufacturing firms. It shows that government regulation of loan interest rates and unstable currency exchange rates least affects firm credit accessibility. The aggregate mean score round off to a score of 4onthe five point likert scale implying that on average, the respondents agreed on effect of external operating environment (credit accessibility) on the relationship between corporate strategies and performance of manufacturing firms. The findings are consistent with a study byAdeoye and Elegunde (2012) which found that external operating environment affected the relationship between corporate strategies and performance of food and beverage manufacturing firms in Nigeria.

\subsubsection{Consumer Behaviour}

The respondents were asked to rate firm consumer behaviour as a component of external operating environment on a Likert type scale of $1-5$, where strongly agree $=5$, Agree $=4$, Disagree $=3$, strongly disagree $=2$ and Not at all $=1$. The results are shown in Table 5 .

\section{Table 5: Descriptive Statistics of Consumer Behaviour}

\begin{tabular}{|l|l|l|}
\hline Statement & Mean & Std. Deviation \\
\hline Consumer behaviour determines demand for firm products & 3.64 & 1.23 \\
\hline Firm has corporate culture of responding to consumer behaviour & 3.44 & 1.10 \\
\hline Consumer perceptions determine the demand for our products & 3.50 & 1.23 \\
\hline The performance of firm products is influenced by consumer habits & 3.39 & 1.12 \\
\hline The firm performance is negatively affected by varied preferences of consumers & 3.42 & 1.16 \\
\hline Consumer attitudes influence firm performance in the market & 3.47 & 1.13 \\
\hline Average & $\mathbf{3 . 4 8}$ & $\mathbf{1 . 1 6}$ \\
\hline
\end{tabular}

Source: Survey data (2018)

The findings in Table 5 indicate that demand for firm products, consumer perceptions and attitude were the main factors affecting the firm external operating environment. Results also indicated that consumer buying habits, preferences and consumer perceptions and lack of firm corporate culture in responding to consumer were factors that least determines the firm external operating environment. The aggregate mean score round off to a score of 3 on the five point Likert type scale, implying that on average, the respondents disagreed on effect of consumer behaviour on the relationship between corporate strategies and performance of manufacturing firms. The findings agreed with the study by Hsiang, Hsien and Dja-Shin (2012) establishing that not all factors in external operating environment has impact on relationship between corporate strategies and performance of Taiwan manufacturing firms.

Table 6: Summary of External Operating Environment

\begin{tabular}{|l|l|l|}
\hline Component & Mean & Standard Deviation \\
\hline Competitive Position & 3.80 & 1.06 \\
\hline Credit Accessibility & 3.54 & 1.12 \\
\hline Consumer Behaviour & 3.48 & 1.16 \\
\hline Aggregate & $\mathbf{3 . 6 1}$ & $\mathbf{1 . 1 1}$ \\
\hline
\end{tabular}

Source: Survey data (2018)

Results illustrated in Table 6 show that on average the characteristics of competitive position had the biggest impact on the firms' external operating environment at a mean of 3.80 and standard deviation of 1.06.This was followed by credit accessibility at a mean of 3.54 and a standard deviation 1.12, while the consumer behaviour had the least impact with a mean of 3.48 and standard deviation of 1.16. On aggregate, the mean score of external operating environment round off to 4 on the five point Likert type scale, implying that the respondents agreed that 
external operating environment affects the relationship between corporate strategies and firm performance. These findings were consistent with studies by Hidayat, Sabarudin and Mu'alim (2015) which established that external environment, affected corporate strategies and performance of manufacturing industries in Indonesia. The findings supported study by byAdeoye and Elegunde (2012) which found that external operating environment affected the relationship between corporate strategies and performance of food and beverage manufacturing firms in Nigeria.

\subsection{Diagnostic Tests}

The Keiser-Meyer-Olkin (KMO) for sample adequacy was done, which obtained values greater than 0.5 as recommended by Malhotra and Dash (2011). Communalities and Eigen values were used in Confirmatory Factor Analysis to test for variable correlations, obtaining values that exceeded 0.4 meaning that no variables were highly correlated as recommended by Rahim and Magna (2005). The study found that all variables met normality threshold of values between -0.1 and +0.1 using Shapiro-Wilk test as recommended by Myoung (2008). The Pearson's correlation coefficients for all the independent variables were positive indicating positive linear relationship between individual independent variables and the dependent variable as recommended by Field (2009). Tolerance values for all variables were above 0.10 and VIF values of below 10 indicating that there was no multicollinearity as recommended by Field (2009). The test of homogeneity by use of Levene's test of homogeneity revealed the $\mathrm{p}$-values for the three predictor variables were greater than the level of significance at .05 implying no homoscedasticity as recommended by Warner (2008).

\subsection{Test of Hypothesis}

The null hypothesis that was tested stated that external operating environment has no significant effect on performance of manufacturing firms in Nairobi City County, Kenya. The hypothesis was tested using step-wise regression model as recommended by Whisman and MacClelland (2005). The first step involved regression of the composite index of corporate strategies measures (independent variable) on firm performance (dependent variable). In the second step, the composite index of corporate strategies measures and external operating environment (moderating variable) were regressed on the firm performance. In the third step, the composite index of corporate strategies measures, external operating environment and an interaction term were regressed on the firm performance measures. The regression results are presented in Tables 7, 8and 9.

Table 7: Model Summary on Moderating Effect

\begin{tabular}{|l|l|l|l|l|}
\hline Model & R & R Square & Adjusted R Square & Std. Error of the Estimate \\
\hline 1 & .687 & 0.472 & 0.468 & 0.26582 \\
\hline 2 & .800 & 0.64 & 0.635 & 0.22021 \\
\hline 3 & .821 & 0.674 & 0.667 & 0.21033 \\
\hline Predictors : Constant, Corporate Strategies \\
\hline
\end{tabular}

The results in Table 7 show adjusted R-square value of 0.468 for the model linking corporate strategies and firm performance. This indicates that $46.8 \%$ of firm performance was explained by corporate strategies. The findings also show that the adjusted $\mathrm{R}$ square value for the model linking corporate strategies and external operating environment to firm performance was 0.635 . This indicates that both corporate strategies and external operating environment explain up to $63.5 \%$ of the variation in firm performance up from $46.8 \%$ that only corporate strategies explained $(0.635>0.468)$. It was also established that, when the interaction term was fitted to the model of external operating environment and corporate strategies, a higher explanatory power on firm performance was obtained, as shown in the increase to $66.7 \%$ (Adjusted $\mathrm{R}^{2}=0.667>0.635>0.468$ ). This indicates that the moderating variable had high effect on the relationship between corporate strategies and firm performance. The findings are consistent with Hsiang, Hsien and Dja-Shin (2012) who established that external operating environment has substantial impact on the relationship between corporate strategies and firm performance. 
Table 8: ANOVA for Corporate Strategies, External Operating Environment and Firm Performance

\begin{tabular}{|c|c|c|c|c|c|c|}
\hline Model & & $\begin{array}{l}\text { Sum } \\
\text { of Squares }\end{array}$ & df & Mean Square & $\mathbf{F}$ & Sig. \\
\hline \multirow[b]{3}{*}{1} & Regression & 9.209 & 1 & 9.209 & 130.324 & 0.000 \\
\hline & Residual & 10.317 & 146 & 0.071 & & \\
\hline & Total & 19.526 & 147 & & & \\
\hline \multirow[b]{3}{*}{2} & Regression & 12.495 & 2 & 6.247 & 128.835 & 0.000 \\
\hline & Residual & 7.031 & 145 & 0.048 & & \\
\hline & Total & 19.526 & 147 & & & \\
\hline \multirow[b]{3}{*}{3} & Regression & 13.155 & 3 & 4.385 & 99.121 & 0.000 \\
\hline & Residual & 6.37 & 144 & 0.044 & & \\
\hline & Total & 19.526 & 147 & & & \\
\hline \multicolumn{7}{|c|}{ Dependent Variable: Firm Performance } \\
\hline \multicolumn{5}{|c|}{ Predictors : Constant, Corporate Strategies } & & \\
\hline \multicolumn{7}{|c|}{ Predictors : Constant, Corporate Strategies, External Operating Environment } \\
\hline
\end{tabular}
Source: Survey data (2018)

Table 8shows an $\mathrm{F}$ statistic value of $(1,146)=130.324$ and $\mathrm{P}=0.000<0.05$ for the model linking corporate strategies to firm performance. This implies that the model linking corporate strategies to firm performance was significant. The findings also revealed an $F$ statistic of $F(2,145)=128.835$ and $p=0.000<0.05$ for the model linking corporate strategies and external operating environment to firm performance. This implies that the model linking corporate strategies and external operating environment to firm performance was significant. It was also established an $F$ statistic of $F(3,144)=99.121$ and $p=0.000<0.05$ for the model linking corporate strategies, external operating environment and interaction term to firm performance. The findings implies that the model linking corporate strategies, external environment and the interaction term to firm performance was significantly fit and that corporate strategies, external operating environment and the interaction term contribute significantly to changes in the performance of manufacturing firms.

Table 9: Model Coefficients for Moderating Effect

\begin{tabular}{|c|c|c|c|c|c|c|}
\hline $\begin{array}{l}\text { Mode } \\
1\end{array}$ & & $\begin{array}{l}\text { Unsta } \\
\text { Coeffi }\end{array}$ & $\begin{array}{l}\text { rdized } \\
\text { ts }\end{array}$ & $\begin{array}{l}\text { Standardized } \\
\text { Coefficients }\end{array}$ & & \\
\hline \multirow[b]{3}{*}{1} & & B & Std. Error & Beta & $t$ & Sig. \\
\hline & (Constant) & 2.455 & 0.092 & & 26.587 & 0.000 \\
\hline & Corporate Strategy & 0.021 & 0.002 & 0.687 & 11.416 & 0.000 \\
\hline \multirow[b]{3}{*}{2} & (Constant) & 1.285 & 0.161 & & 7.959 & 0.000 \\
\hline & Corporate strategy & 0.011 & 0.002 & 0.353 & 5.494 & 0.000 \\
\hline & $\begin{array}{ll}\text { External } & \text { Operating } \\
\text { Environment } & \\
\end{array}$ & 0.461 & 0.056 & 0.529 & 8.231 & 0.000 \\
\hline \multirow[b]{4}{*}{3} & (Constant) & 2.86 & 0.436 & & 6.562 & 0.000 \\
\hline & Corporate Strategy & 0.028 & 0.010 & 0.919 & 2.745 & 0.007 \\
\hline & $\begin{array}{ll}\text { External } & \text { Operating } \\
\text { Environment } & \\
\end{array}$ & 0.059 & 0.117 & 0.068 & 0.503 & 0.616 \\
\hline & Interaction Term & 0.01 & 0.003 & 1.614 & 3.864 & 0.000 \\
\hline
\end{tabular}

Source: Survey data (2018)

Performance of Manufacturing Firms $=2.860+0.028$ (Corporate Strategies) +0.059 (External Operating Environment) +0.01 (Corporate Strategies * External Operating Environment)

The findings in Table 9 shows that the moderating effect of external operating environment on the relationship between corporate strategies and firm performance was positive and significant since the interaction term had a positive and significant beta coefficient ( Beta $=0.010, \mathrm{P}<0.000$ ). The findings corroborated findings by Henk, Niels, Ernst, Marten and Antonio (2012) that firms operating environment determined its adaptability of corporate strategies towards performance. The findings are also consistent with Hsiang, Hsien and Dja-Shin (2012) who established that operating environment has positive and significant impact on relationship between corporate strategies and firm performance. Results indicate that when the interaction of corporate strategies and external operating environment was introduced to the relationship between corporate strategies as well as external operating environment and firm performance, the effect of corporate strategies is increased ( from Beta $=0.011$ to 0.028 ). This implies that through interaction with the external operating environment, the effect of corporate strategies improves performance. The findings therefore suggest that the manufacturing firms need to analyze external 
operating environment in developing effective corporate strategies towards superior performance.

There was consensus thatexternal operating environment affects this relationship. The respondents had a general feeling that government interventions such as policies, legislations and regulations do not support growth of manufacturing firms. According to most of the respondents unpredictable consumer behaviour was the main challenge to the manufacturing firms. The respondents also felt that market competition and credit accessibility were other factors that pose challenges in the effectiveness of corporate strategies on firm performance.

\subsection{CONCLUSION AND RECOMMENDATIONS}

The study reveals that the effect of external operating environment on firm performance is positive and significant. Based on the results, it can be concluded that conducive external operating environment is key for a firm to succeed in achieving superior performance. That is, manufacturing firms should have competitive position, credit accessibility and adequately manage consumer behavior. The findings suggest that manufacturing firms should be scanned and integrated in the development and execution of corporate strategies to succeed in performance.

The study recommends that the governments develop policies and legislative framework to regulate manufacturing sector's competition practices, provide guidelines on new industry entrants and remove some entry barriers. Further, the governments need to develop and maintain conducive industry supporting infrastructure to enhance distribution channels. Based on the study findings, it is reasonable to recommend that governments review fiscal and monetary policies in the areas of taxation regime and domestic borrowing since they make cost of production to be very high and restrict credit accessibility by the manufacturing firms. It is further recommended that firm policy makers develop effective customer awareness programs to address consumer perceptions and attitude towards their products.

The study contributes to empirical literature on moderating effect of external operating environment on the relationship between corporate strategies and firm performance. Specifically, the study found out that external operating environment significantly affects this relationship in manufacturing firms. Therefore, the study findings contributes to the knowledge of strategic management by providing empirical evidence on effect of external operating environment on relationship between corporate strategies and firm performance. The study contributes to the theoretical literature by supporting the Institutional theory which contends that firms which adopt effective corporate strategies enhance performance by adequately addressing environmental uncertainty. The study findings were in harmony with theory, that superior firm performance results from adequate management of environmental dependencies and employing appropriate strategies to fit in the external environment, thus achieving higher performance. In this case, the firm environment determines effectiveness of corporate strategies on firm performance.

\section{REFERENCES}

Adeoye, A.O. \&Elegunde, A.F.(2012).Impacts of external business environment on organizational performance in the food and beverage industry in Nigeria. British Journal of Arts and Social Sciences, 6 (2), 194-208

Burns N, Grove S.(2007). Understanding nursing research: Building an evidence-based practice.Journal of Advanced Nursing, 2 (7), 60-96.

Chin J., Widing II, R., \&Paladino, A. (2004). Influence of Resource Dependency Theory on Firm Performance, Managing the Competitive Environment. University of Melbourne

Cooper, D. R., \& Schindler. P. S. (2008).Business research methods. 8th Edition.USA: McGraw-Hill.

Davis, G. F., \& Cobb, J. (2010). Resource Dependence Theory: Past and future. Research in the Sociology of Organizations, 28, 21-42

DiMaggio, P. J., \& Powell, W. W. (1983). The iron cage revisited: Institutional isomorphism and collective rationality in organizational fields. American Sociological Review, 48, 147-160.

Eljelly, M.A. (2004). Liquidity - Profitability Tradeoff: An empirical investigation in an emerging market. International Journal of Commerce \& Management. 14(2), 54-78

Field, A. P. (2009). Discovering statistics using SPSS. $2^{\text {nd }}$ Edition. Sage publications.

Filbeck, G. and T. M. Krueger, (2005). An analysis of working capital management results across industries. American Journal of Business. 20(2), 11-18.

Fisher, A. A., Laing, J., \&Stoeckel, J. (1985).Guidelines for overcoming design problems in family planning operations research.Studies in Family Planning, 16(2), 88-94

Foss, N.J. and Knudsen, T. (2003).The resource-based tangle: Towards a sustainable explanation of competitive advantage. Managerial and Decision Economics, 24, 291-307.

Foya, A.H., Kilika, J.M. \&Muathe, S.M.A. (2015). Relating technology based CRM to service quality in the telecommunications industry in Arusha city, Tanzania. Science Journal of Business and Management, 3 (6):209-218

Grant, P. \&Perren, L (2002). Small business and entrepreneurial research: Meta-theories, paradigms and prejudices .International Small Business Journal, 20(2), 76-93 
Greenwood, R., Oliver, C., Suddaby, R. \&Sahlin-Andersson, K. (2008). The Sage Handbook of Organizational Institutionalism. Sage, London.

Hair, J.F., Money, A.H., Samouel,P., \&Page,M, (2007). Research methods for business. England. John Wiley \& Sons Ltd.

Hawawini G, Subramanian V, \&Verdin P (2003).Is performance driven industry- or firm- specific factors? A new look at the evidence. Strategic Management Journal vol. 24: 1-16.

Henk, W. V., Niels, W.,Ernst,V.,Marten, S. \&Antonio J. V. (2012). Contingency fit, institutional fit, and firm performance: A meta-fit approach to organization-environment relationships. Organization Science, 23 (4), $1040-1054$

Hidayat, R., Sabarudin, A., \&Mu'alim (2015). Effects of environmental factors on corporate strategy and performance of Manufacturing Industries in Indonesia. Journal of Industrial Engineering and Management ,8(3), 763-782

Hillman, A.J., Cannella, A.A. and Paetzold, R.L. (2000). The resource dependence role of corporate directors: Strategic adaptation of board composition in response to environmental change. Journal of Management Studies, 37, 235-256.

Hosseini, S.M. \& Sheikhi,N (2012). An empirical examination of competitive capability's contribution toward firm performance:Moderating role of perceived environmental uncertainity. International Business Research,5(5), 116-131

Hsiang, F. T, Hsien, B.W., \&Dja-Shin, W. (2012). The moderating role of environmental dynamism on the influence of innovation strategy and firm performance. International Journal of Innovation, Management and Technology, 3(5), 517-520

Jong, G., Phan, B \&Ees, H. (2011). Does the meta-environment determine firm performance? Theory and evidence from European multinational enterprises. International Business Review, 20, 454-465.

Kenya Association of Manufacturers (2016).Kenya manufacturers and exporters directory. Nairobi

Kim, L., \& Lim, Y. (1988). Environment, generic strategies, and performance in a rapidly developing country: A taxonomic approach. Academy of Management Journal, 31(4), 802- 827.

Konar, S. and Cohen, M.A. (2001) Does the market value environmental performance? Review of Economics and Statistics, 83, 281-289.

Kothari, C. R. (2004). Research methodology: Methods and techniques. 2nd Edition. New Delhi: New Age Publications.

Malhotra, N. K., \& Dash, S. (2011). Marketing Research an Applied Orientation. New Delhi: Pearson.

Mazdeh, M. M., Moradi, K., \&Mazdeh, H. M. (2011). Strategic planning model for Start-ups: A case study of Iranian packaging industry. Management Science Letters, 1, 157-166

Mugenda, O. M. \&Mugenda, A. G., (2003).Research methods; quantitative and approaches 4th Edition. Acts Press. Nairobi

Myoung, P.H, (2008). Univariate analysis and normality test using SAS, Stata, and SPSS. Indiana University

Neneh, N \&Vanzyl, J. (2014). Growth intention and its impact on business growth amongst SMEs in South Africa. Mediterranean Journal of Social Sciences, 5 (10), 172- 183.

Njuguna, J.W.K., Munywoki, J., \&Kibera, F. (2014).Influence of external organizational environment and performance of community based HIV and AIDS organizations. European Scientific Journal, 10(1), 405-426.

Padachi, K. (2006). Trends in working capital management and its impact on firms' performance: An analysis of Mauritian small manufacturing firms. International Review of Business Research Papers. 2(2), 45 - 58.

Patton, M. Q. (2002). Qualitative evaluation and research methods.3rded.Thousand Oaks: Sage.

Pearce, J. A., \& Robinson, R. B. (2013). Strategic Management: Planning for Domestic and Global Competition (13th Ed.).New York: McGraw-Hill Irwin

Porter, M. (2008). The five competitive forces that shape strategy. Harvard Business Review. 1, 79-93.

Powell, T. C. (1996). How much industry matter? An alternative empirical test. Strategic Management Journal, $17,323-334$.

Raheman, A. and Nasri, M., (2007). Working capital management and profitability - Case of Pakistani firms. International Review of Business Research Papers. 3 (2), 275 - 296.

Rahim, M. A., \&Magner, N. R. (2005). Confirmatory Factor Analysis of the styles of handling interpersonal conflict: Factor Model and its Intervariance across groups. Journal of Applied Psychology, 80, 122-132.

Saunders, M., Lewis, P., \& Thornhill, A. (2007).Research methods for business students, $5^{\text {th }}$ Edition, Great Britain, Prentice Hall.

Scott, W.R. (1995) Institutions and Organizations. SAGE Publications, Thousand Oaks.

Sekaran, U., \&Bougie, R. (2009).Research methods for business, 5th Edition. Wiley publication.

Shapiro, S., Carlson, L., Astin, J., \& Freedman, B. (2006). Mechanisms of mindfulness. Journal of clinical psychology. 62, 373-86.

Spanos, Y. E., Zaralis, G., \&Lioukas, S. (2004). Strategy and industry effects on profitability: Evidence from 
Greece. Strategic Management Journal, 25(2), 139-165.

Tan, M., \& Liu, J. (2014). Paths to success: An ambidexterity perspective on how responsive and proactive market orientations affect SMEs' business performance. Journal of Strategic Marketing, 22(5), 420-441.

Warner, M. (2008). Reassessing human resource management with Chinese characteristics: An overview. International Journal of Human Resource Management, 19(5): 771-801

Whisman, M. A. \&MacClelland, G. H (2005). Designing, testing, and interpreting interaction and moderator effects in family research. Journal of family Psychology, .19(1), 111-120.

Zikmund, W. (2003).Exploring marketing research. $7^{\text {th }}$ Ed.). USA. Thompson, South Western. 